\title{
Marketing-oriented approach to evaluating the strategy of distribution management for innovative products in logistics
}

\author{
IVAN GRYSHCHENKO \\ Rector, Kyiv National University of Technologies and Design, UKRAINE \\ OLGA CHUBUKOVA \\ Department of Economic Cybernetics and Marketing, \\ Kyiv National University of Technologies and Design, UKRAINE
}

OLENA BILOVODSKA

Department of Economic Cybernetics and Marketing, Kyiv National University of Technologies and Design, UKRAINE

OLENA GRYSHCHENKO

Research Sector, Sumy State Pedagogical University named after AS Makarenko, UKRAINE

\author{
YULIIA MELNYK
}

Department of Business Economics and Administration, Sumy State Pedagogical University named after AS Makarenko, UKRAINE

\begin{abstract}
A strategy combines directions ranging from product development, also includes directly the products production and distribution, as well as strategies aimed at improving products, interacting with consumers, finding and expanding new markets, etc. So the formation and evaluation of strategy of distribution management in logistics which ensures the achievement of consumer's needs and requests is an important stage for the increase the company's efficiency.

The purpose of the paper is to evaluate the strategies of distribution management for innovative products in logistics by the chemical companies according to the consumer's perspectives. To achieve that, the main indicators on the chemical industry in the global market are analyzed. Also the business trends of strategic activities in the chemical company on the one of the basic company for this industry are systemized. The authors combined them into four main groups: innovation, digitalization, integration and ecologization. Based on the author's methodical approach the strategy of distribution management for innovative products in logistics by the chemical company is evaluate. According to the evaluation results it is determined that the strategy needs to be improved by growing rate of the benefit indicator compared to the rate of price growth. Also the complex of recommendations to improve the strategy of distribution management for innovative products in logistics according to consumer's perspectives which forms the basis for the methodology of the selection the most objective strategic alternative in the chemical company.
\end{abstract}

Key-Words:- distribution, strategy, chemical industry, company, evaluation, consumer, innovative product, logistics

Received: November 12, 2019. Revised: May 9, 2020. Accepted: May 18, 2020. Published: May 21, 2020.

\section{Introduction}

Nowadays, chemical industry companies face difficulties in supporting their competitiveness. This is because of global megatrends influence in different industries including the chemical industry. It is essential to have a well-established and developed strategy and management system capable of responding to internal and external changes. Most of the existing methods for evaluating the strategy are general and based only on internal business indicators, they do not reflect market efficiency, which is based on indicators of the market. The company's strategy should accord with the interests of the consumer; especially it concerns the production and distribution of innovative products. 
So, to evaluate the strategy of distribution management of chemical companies as well, it is important to consider the indicators from the perspective of the consumer, which characterize the degree of satisfaction of their needs. Evaluation of the strategy of distribution management from the perspective of the consumer makes it possible to determine its correspondence to the external environment. It must be noted that to improve the strategy of distribution management, Ukrainian companies must follow the main international trends in the chemical industry: innovation, digitalization, integration, and ecologization. Integration into the international business community, renovations, reforming the financial service market which allows to improve its functioning and increase its positive impact on the development of the national economy [1], [2], [3] and instant innovative activity will allow Ukrainian companies from the development gap. The abovementioned thesis forms the basis of the chemical industry company development.

\section{Literature review}

Many researchers emphasize that the distribution or sales strategy occupies a key position in comparison with communication, product and pricing strategies. Thus, Sam Amico (n.d.) determines "sales strategy" as a plan by a business or individual on how to go about selling products and services and increasing profits. Sales strategies are typically developed by a company's administration, along with its sales, marketing, and advertising managers [4].

Zolters, Sinha \& Lorimer (2017) define "sales strategy" as "a plan by which the organization performs its sales functions, the goals of which are selling products or services or both, and to increase profits by organic growth. An important part of a sales strategy is defining the customer base and understanding the added value your organization can bring to your customers" [5].

HubSpot Inc. points out that "sales strategy" is "an approach to selling that allows the sales force to position the company and its product(s) to target customers in a meaningful, differentiated way" [6].

Storbacka, Ryals, Davies, \& Nenonen (2009) define that "sales strategies have implications for the sales process and the interface of sales not just with customers but also within the organization" [7].

Thus, based on the conducted study of concepts, it can be noted that "distribution/sales strategy" is a part of the overall strategy of the company, the main goal of which is not only to bring products to consumers but also to take into account their desires and wants.

Many scholars study the features of innovation in marketing and other areas of business. So, Illiashenko (2010) developed "a methodological approach to management of enterprises innovative activity basing on the principles of innovations marketing. Its practical realization enables purposeful management of an innovation and introduction of the market-oriented strategy of innovative development for the national producers" [8].

Babenko (2013, 2019) investigated "the process of formalization of management of technological innovations" [9], [10]. This author and Romanenkov, Yakymova \& Nakisko (2017) developed "the detailed model of multicriteria optimization of innovative process management at an enterprise in the face of risks, which describes dynamics of the studied process to the full" [11].

Pererva, Besprozvannykh, Tiutlikova, Kovalova, Kudina, \& Dorokhov (2019) improved "the method of selection of innovative projects on the rating assessment of their economic efficiency. They proposed "to carry out an integrated assessment, which involves ranking of the projects on the level of individual indicators of economic efficiency" [12].

A sufficiently thorough study to the evaluation of distribution in strategic management is reflected in the works of foreign and domestic scientists. In particular, Huang, Jiang (2018) proposed "a cooperative clustering based multimodal estimation of distribution algorithm (EDA) and technique which can not only explores and exploits the promising regions in the search space effectively but also obtain the global optima superior to the typical multimodal EDA" [13].

Wang, Fan, \& Gong (2018) proposed "a method to decide what kinds of optimizing purchasing strategies should be adopted for the retailers in different areas, the positive strategies or the conservative strategies" [14].

Kurbatska, Ilchenko, \& Kadyrus (2016) proposed "the complex of marketing strategies of distribution activities in the agricultural enterprise" [15].

Polishchuk (2015) suggested "to measure the effectiveness of a marketing (or distribution) strategy using the "marketing return" as a ratio of net income to the costs incurred for marketing activities". Also this author proposed the efficiency of the marketing strategy realization by the enterprise to measure the totality of the following 
indicators: receivables for goods, works, services at the end of the year; net income from sales of products; gross profit; duration of receivables turnover for goods; marketing costs; the share of marketing costs in the costs of the enterprise and others [16].

Summing up, unfortunately, the problems of evaluating strategy of distribution management in the process of launching innovative products taking into account marketing benchmarks, are insufficiently researched. The chemical industry is not deeply explored as well. However it should be crucial for economic growth in modern realities. So the purpose of the paper is to evaluate the strategies of distribution management for innovative products in chemical companies according to the consumer's perspectives.

\section{$3 \quad$ Materials and methods}

The empirical base of this study consists of practice materials of national and world markets of chemical industry, data from the European Chemical Industry Council, European Commission, U.S. Department of Commerce, State Statistic Service of Ukraine. The methodological basis of the study is a set of scientific techniques and methods of scientific knowledge, including formal-logical method and comparative analysis (in the study of analysis of the main indicators of the chemical industry in the global market), methods of graphical and factor analysis, decomposition, structural-logical approach (in the systematization of the business trends of strategic activities in chemical company). The evaluation of the strategy is based on the approach presented by Bilovodska (2016) [17]. It is advisable to carry out the evaluation of the strategy of distribution management from the consumer's perspectives on two indicators - the prices for the products of the enterprise and the value of the indicator, which takes into account the evaluation of the benefits that consumers receive from the products of the enterprise. It is formed on the differential method, methods of complex estimation, coefficient (Spearman's coefficient).

\section{$4 \quad$ Results and discussion}

\subsection{The analysis of the main indicators of the chemical industry in the global market}

In Landscape of the European Chemical Industry (2018) is shown that world chemical sales were $€ 3,360$ billion in 2016, up 0,4\% from $€ 3,347$ billion in 2015. In 2015, the largest share of the market of the chemical products sale belonged to the Asian market $-61 \%$. The second place was occupied by Europe, with a market share of $17.4 \%$. It should be mentioned that in 2016 including nonEU countries, total European chemical sales reached $€ 597$ billion, or 17.8 percent of world output. Besides as it was shown at the European Commission official website the chemical industry generates 1.1 percent of EU gross domestic product [18], [19].

According to Chemicals trends analyzer (2017), the third place was taken by North America, whose market share was $16.5 \%$. Latin America owned $3.8 \%$ of the world chemical market, and $1.3 \%$ - the rest of the world [20].

Fig. 1 shows the growth in volumes of the chemical industry (except for pharmaceutical products) in 2015-2020 compared with the previous year (based on [21], [22], [23], [24], [25]).

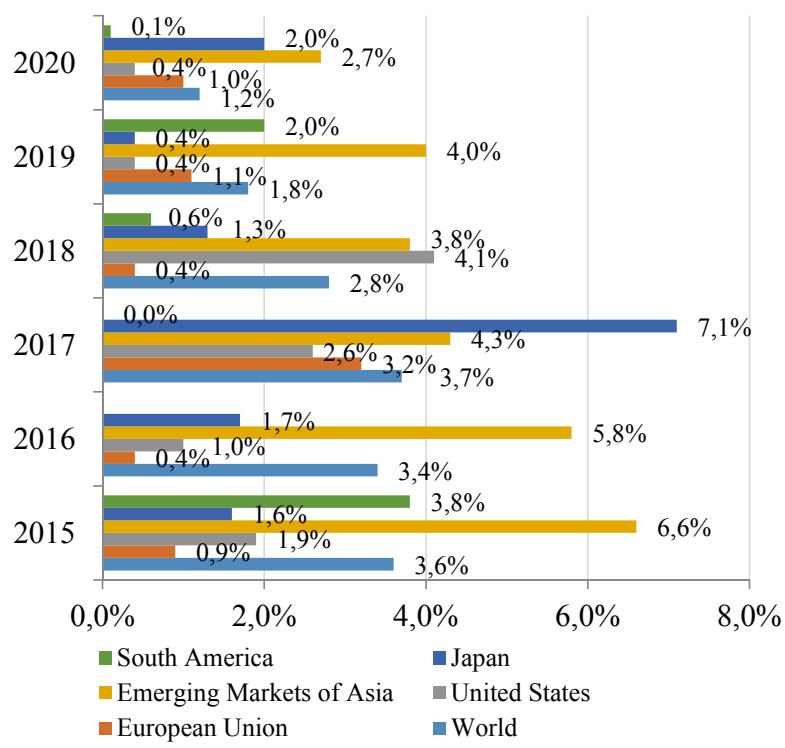

Fig. 1 . The volume of the chemical industry (except for pharmaceutical products) in 2015-2019 (real change compared with previous year) and outlook for 2020

In general, rapid growth rates were observed in the European Union in 2017 (2017: + 3.2\%, 2016:+0.4\%, 2015:+0.9\%) [21], [22], this was the result of the growing demand of local consumers and manufacturers and an increase in exports. And rapid fall were observed in 2018 (2018: $+0.4 \%$, 2019: + 1.1\%) [23], [24].

The landscape of the European Chemical Industry (2019) reports that China ranked first by 
sales in 2016, where chemicals surged by $€ 50,8$ billion in 2016 to reach $€ 1,331$ billion [26]. But as mentioned by BASF Group (2016-2019) the chemical industry in Asia saw a lower fall (2015: $+6.6 \%, 2016:+5.8 \%, 2017:+4.3 \% ; 2018:+3.8 \%$, 2019: +4.0\%) [21], [22], [23], [24]. The reason was the decline in growth in China. Thought Japan showed unusually strong growth in 2017 and sudden fall in 2018 and 2019. In South America, chemical production was negatively impacted by Hurricane Harvey. Chemical production in the United States nevertheless rose by $4.1 \%$ in 2018 and lowered by $0.4 \%$ in 2019 [23], [24]. Growth forecasted only in Japan by $2.0 \%$ in 2020 [25].

The growth rates of the global chemical industry by segments (\% change (y-o-y)) in 2015 and the outlook for 2020 are given in Fig. 2 based on $[20]$.

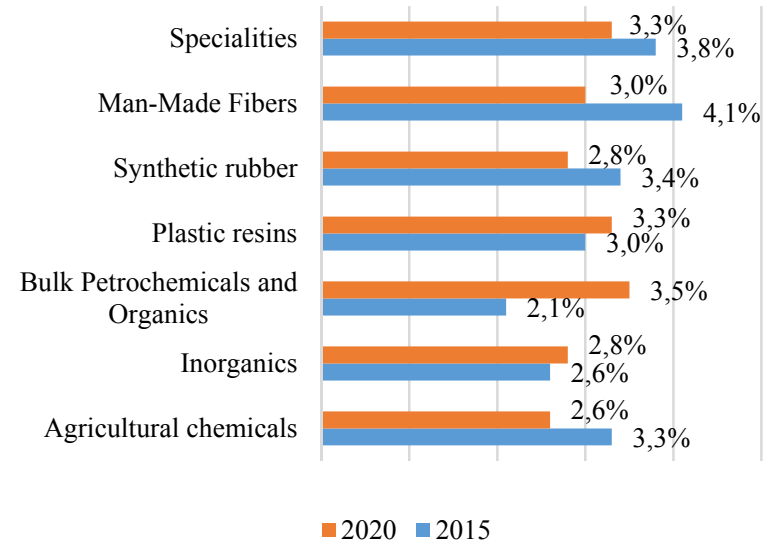

Fig. 2. Global chemicals production outlook by segment ( $\%$ change y-o-y)

According to the landscape of the European Chemical Industry (2020) the EU chemical industry ranks second by sales, slightly ahead of the United States. Including non-EU countries, total European chemicals sales reached $€ 694$ billion in 2018 , or $20.7 \%$ of world output. But China has passed Europe to top the global sales ranking. In 2018, sales from the 30 largest chemical-producing countries totalled $€ 3,131$ billion. Twelve of the top 30 were in Asia. Their $€ 1,886$ billion of sales contributed to top 30 chemicals sales and captured $56.4 \%$ of world chemicals sales (see Fig. 3) [26].

Sales were positively impacted by higher sales prices in all regions and almost all business areas, as well as higher volumes in the oilfield and mining chemicals and lubricant and plastic additives businesses. Negative currency effects, mainly from the U.S. dollar, and the transfer of BASF's leather chemicals business to the Stahl group dampened sales development. The performance chemicals sales are given in Fig. 4.

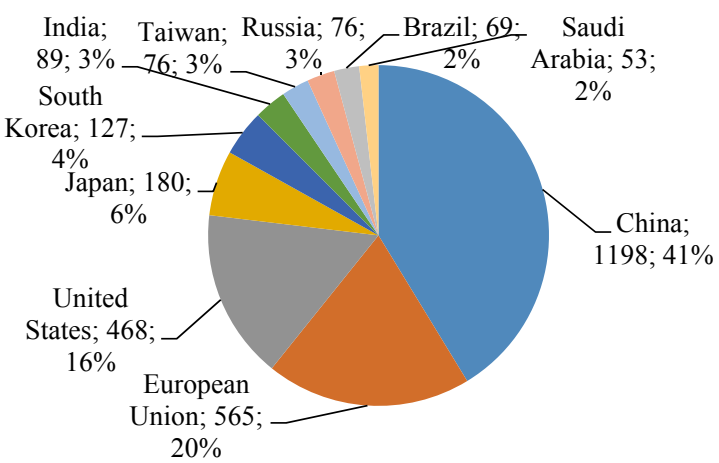

Fig. 3. Chemicals sales by country in 2018: top 10 (compiled based on [26]), billion euro, $\%$

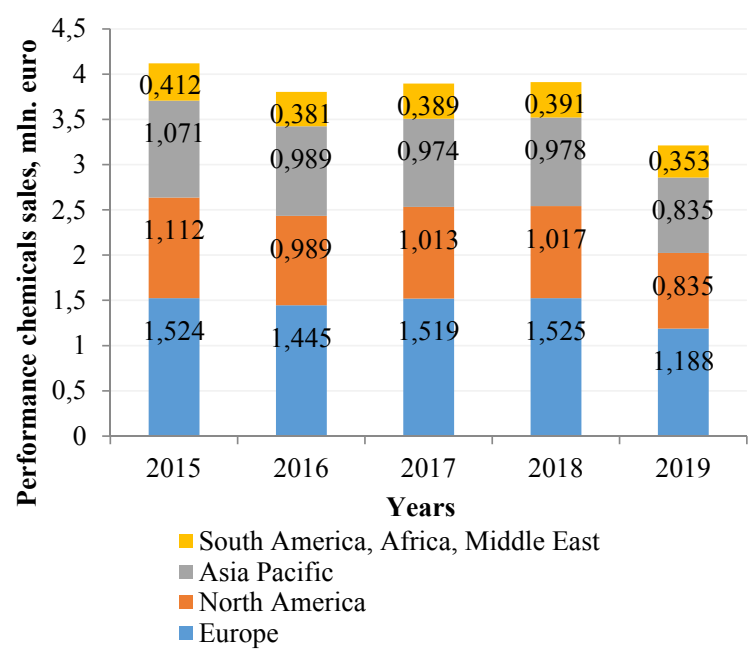

Fig. 4. Global performance chemicals sales (compiled based on [27], [28], [29], [30], [31])

The fifteen countries that exported the highest dollar value worth of chemicals during 2018 encompassing both organic and inorganic chemicals are given in Table 1 .

Table 1 . Chemical exports by country in 2018

\begin{tabular}{|l|c|c|}
\hline \multicolumn{1}{|c|}{ Country } & $\begin{array}{c}\text { Export, } \\
\text { billion US\$ }\end{array}$ & $\begin{array}{c}\text { \% of total exported } \\
\text { chemicals }\end{array}$ \\
\hline China & 80 & 13.7 \\
\hline United States & 52.7 & 9.1 \\
\hline Belgium & 41.7 & 7.2 \\
\hline Germany & 36.3 & 6.2 \\
\hline Ireland & 34.1 & 5.9 \\
\hline South Korea & 30.9 & 5.3 \\
\hline Netherlands & 30.7 & 5.3 \\
\hline Japan & 24.8 & 4.3 \\
\hline Switzerland & 21.3 & 3.7 \\
\hline India & 19.8 & 3.4 \\
\hline Singapore & 17.5 & 3 \\
\hline Saudi Arabia & 17 & 2.9 \\
\hline
\end{tabular}




\begin{tabular}{|l|l|l|}
\hline France & 15.6 & 2.7 \\
\hline Taiwan & 13.7 & 2.3 \\
\hline United Kingdom & 12.7 & 2.2 \\
\hline
\end{tabular}

Source: Compiled based on [32]

By value, the listed 15 countries shipped over three-quarters (77.1\%) of global chemical exports in 2018. Among the above countries, the fastest-growing chemicals exporters since 2014 were: India (up 46.9\%), China (up 32.3\%), Ireland (up 25.2\%) and South Korea (up 10\%).

Five top countries posted declines in their exported chemicals sales namely: Germany (down 18.8\%), France (down -12.1\%), Japan (down 9.2\%), Singapore (down $-7.1 \%$ ) and United States (down-4.2\%) [32].

According to Chemical \& Engineering News, the following companies are major players in global chemical sales in 2018: DowDuPont (United States, chemical sales: $\$ 86.0$ billion), BASF (Germany, \$74.1 billion), Sinopec (China, $\$ 69.2$ billion), Sabic (Saudi Arabia, $\$ 42.1$ billion), Ineos (Unitad Kindom, $\$ 37.0$ billion), Formosa Plastics (Taiwan, \$36.9 billion), ExxonMobil (United States, \$32.4 billion), LyondellBasell Industries (Netherlands, $\$ 30.8$ billion), Mitsubishi Chemical (Japan, \$28.7 billion), LG Chem (South Korea, \$25.6 billion), Reliance Industries (India, $\$ 25.2$ billion), PetroChina (China, $\$ 24.8$ billion), Air Liquide (France, \$24.3 billion), Toray Industries (Japan, \$18.7 billion), Evonik Industries (Germany, \$17.8 billion) [33].

According to the information provided above, we can assert that the role of the chemical industry continues to grow on a worldwide scale.

In the case of Ukraine, the chemical industry is one of the six classical branches of the Ukrainian economy that are "basic" ones: extractive, metallurgical, chemical and petrochemical, food industry, power engineering, and machine building. Today, despite the growing importance of this industry on a worldwide scale and the local potential available, the Ukrainian chemical industry needs additional capital investments and further development.

Table 2 shows the main indicators of the chemical industry of Ukraine in comparison with the developed countries of the world.
Table 2. Indicators of the chemical industry of Ukraine and the developed countries of the world

\begin{tabular}{|c|c|c|c|c|c|}
\hline \multirow[b]{2}{*}{ Country } & \multicolumn{5}{|c|}{ Indicator } \\
\hline & 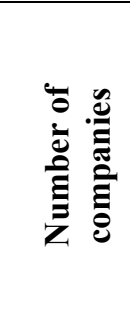 & 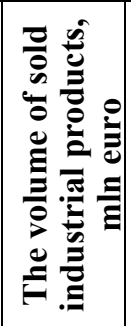 & 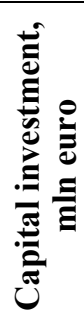 & 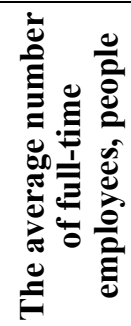 & 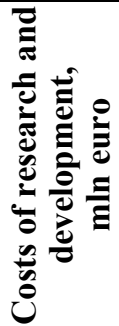 \\
\hline Germany & 2000 & 184700 & 7400 & 447064 & 10500 \\
\hline $\begin{array}{l}\text { United } \\
\text { Kingdom }\end{array}$ & 3460 & 59500 & 4700 & 140000 & 6300 \\
\hline Finland & 400 & 19700 & 851 & 33400 & 429 \\
\hline Belgium & $>720$ & 65000 & 2100 & 90000 & 4000 \\
\hline Italy & 2800 & 52000 & 1600 & 108100 & 520 \\
\hline Poland & $>11000$ & $>35000$ & - & 279000 & 700 \\
\hline USA & $>10000$ & 689655 & - & 811000 & 78448 \\
\hline Ukraine $^{*}$ & 1611 & 3368 & 126 & 83000 & - \\
\hline
\end{tabular}

Notes: “*” - data on Ukraine are given for 2015, data on the rest of the countries are given for 2016 ; “_"“- no data available.

Source: Compiled based on [18], [26], [34], [35].

The chemical industry supplies inputs to almost all sectors of the economy, its prosperity also has important implications for downstream chemicals users (i.e., the users and buyers of its products). Beyond chemical manufacturers themselves, the biggest industrial users of chemicals are the rubber \& plastics, textiles, construction, computer production, and pulp \& paper sectors (see Fig. 5 (based on [36])).

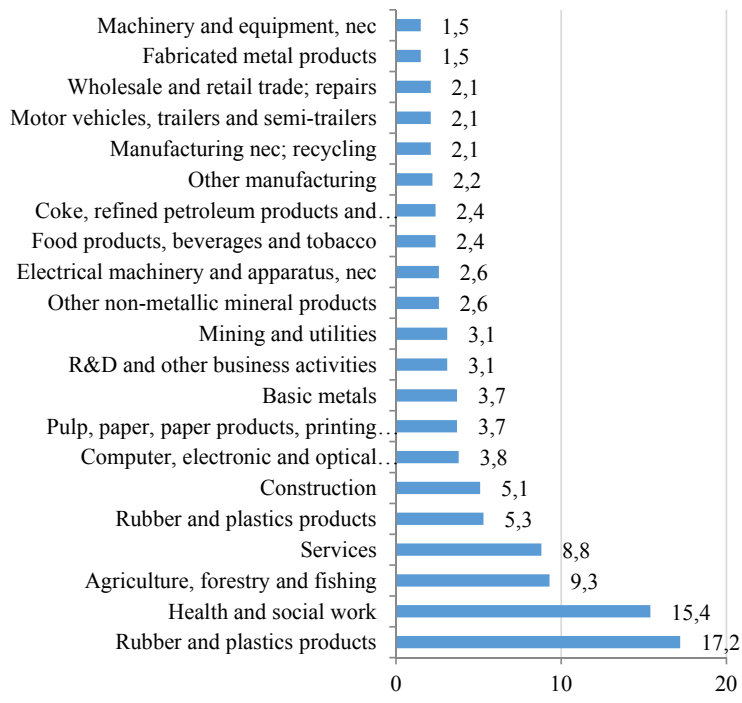

Fig. 5. Customer sectors of the global chemical industry (excl. chemical manufacturers), $\%$

According to foregoing positions, we stand that the chemical industry is one of the key 
industries at the world level. The USA, Japan, and the EU are leaders of its industry. In terms of Ukraine, the chemical industry is one of the six classical branches of the Ukrainian economy that are "basic" ones. Despite the growing importance of this industry on a worldwide scale and the local potential available, the Ukrainian chemical industry needs additional capital investments and further development.

\subsection{The systematization of the business trends of strategic activities in chemical company}

Thus, Ukraine lags behind the advanced countries of the world in terms of indicators of the chemical industry. In particular, Ukraine has lower indicators of the volume of sold industrial products (for example, sales in Germany are 54.8 times bigger, in Great Britain - 17.7 times bigger, in Poland - 10.4, in the USA - 204.8 times). And, also, capital investment should be intensified (for example, sales volumes in Germany are 58.7 times bigger, in Great Britain -37.3). Summing up the conducted statistical survey it must be noted that the difficulties in up-to-date data collection were met because of the lack of systematic control and other factors.

To improve its position in the world market, Ukraine (in addition to updating the material and technical base, training of qualified personnel and increasing the investments in research and development) needs to follow the advanced trends in the global chemical industry, as a result of megatrends, among which are the following: globalization, innovation development, sustainability, and the circular economy. Inspired by [20] we provided an analysis of the compliance of PGSC "Sumykhimprom" strategic initiatives with global trends in the development of the chemical industry (see Fig. 6 based on [20] and [37]).

So, we have combined megatrends into four main groups: Innovation, Digitalization, Integration, and Ecologization. A strategic analysis of the company was carried out and the main activities were highlighted. The innovation as global trends imperative seems particularly acute in today's high-velocity marketplace as every executive is aware of how innovative entrants have disrupted entire sectors in recent years [38]. Innovative activity is implemented through Business remodeling, which is confirmed by continuous improvement of production capacities, improvement of the management and distribution system. The company also strives to meet international requirements for the Quality management system ISO 9001. New improved types of products that maximally meet the needs of consumers and increase the competitiveness are constantly developing and introducing into production.

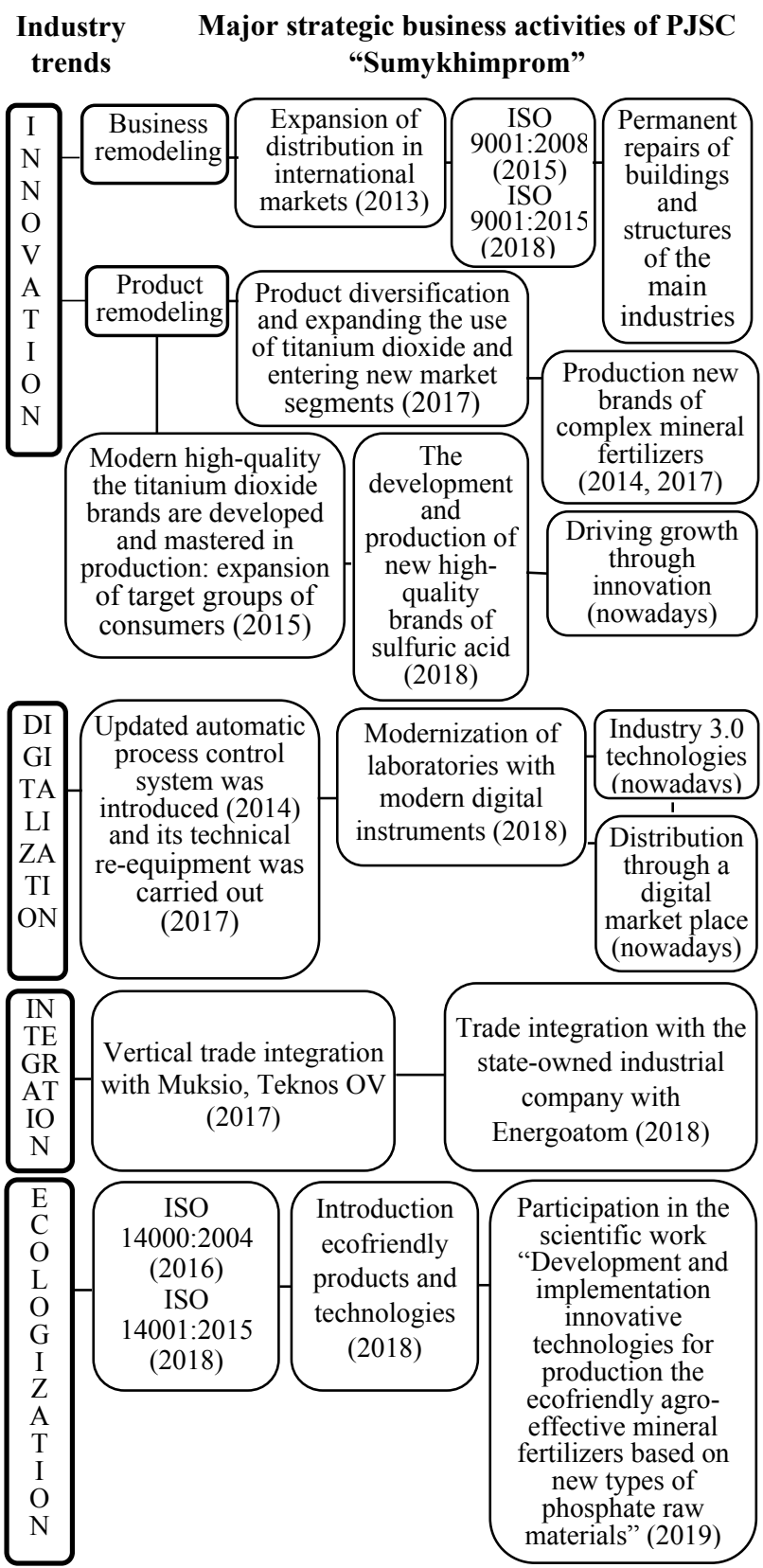

Fig. 6. Chemical industry trends and PJSC "Sumykhimprom" activities

Digitalization is not a technical evolution but rather an industrial and social revolution driven by citizens and customers [39]. There are endless possibilities to change the way we live, work and communicate with new technology. Change is appearing at a speed we have never seen before. So 
domestic enterprises are significantly behind in the pace and level of digitalization, but they are taking active steps to achieve the future of smart, such as some Industry 3.0 technologies and digital instruments, updating automatic process control systems, trading in the digital market place and others.

Businesses across the globe are advocating for connected experiences, which is one of the main prime objectives of Digital Transformation. Business-to-Business integration helps organizations streamline their digital transformation journey by creating a network of data sources, applications, that thrives on communication, collaboration, and connection [40].

While the last decade was ruled by cloudbased integration applications, the year 2020 and the decade following it will witness a major surge in hybrid integration with the promise of delivering the idea of a connected business world.Vertical integration with suppliers and consumers provides PGSC Sumykhimprom with additional perspectives. The strategic direction for the future is integration with international companies in the chemical industry.

Implementation and development of ecofriendly technologies make it possible to grow environmentally friendly products with minimal impact on the environment.

Taking into account the above-mentioned, the issues of evaluation of the products' strategic business activities as a whole and innovative products, in particular, becomes extremely relevant and meets the present needs. As the evaluation of the strategy allows us to consider comprehensively various aspects of company functioning, which directly or indirectly affect or may affect the business processes, as well as determine the possible consequences of implementing the chosen strategy.

\subsection{Evaluating the strategy of distribution management for innovative products in logistics}

According to author's previous studies [17], [41], [42] it is advisable to evaluate the strategy from the perspective of the consumer using two factors: the prices for the company products and the value of the indicator that takes into account the benefits that consumers receive from the company products. This approach should be the base to evaluating the strategic activities of distribution management for innovative products in logistics. It combines qualitative approaches to determine the relevance of the strategy to the external environment. The value of the indicator that takes into account the benefits is calculated on the basis of evaluating the specific parameters to a particular type of product according to the formulas:

$$
\begin{aligned}
Q_{b i} & =\sum_{j=1}^{n} V j \cdot \frac{P \min }{P i j} \\
Q_{b i} & =\sum_{j=1}^{n} V j \cdot \frac{P i j}{P \max }
\end{aligned}
$$

$P_{i j}$ - the $j$-th indicator of benefits $(j=1,2,3$, $\ldots, k)$ of the product $\mathrm{i}(\mathrm{i}=1,2,3, \ldots, 1)$;

$\mathrm{P}_{\operatorname{maxj}}$ - the maximum value of the $\mathrm{j}$-th indicator of the product's benefits from all similar products;

$P_{\text {minj }}$ - the minimum value of the $j$-th indicator of the product's benefits from all similar products;

$\mathrm{V}_{\mathrm{j}}$ - the weighting factor of the benefit indicator $\mathrm{j}$ [17].

So we have chosen PJSC "Sumykhimprom" as an object of the research. This company is a chemical industry company. It produces mineral fertilizers, coagulants and additives to cement, acid, titanium dioxide and pigments and other types of chemical products. Analyzing company uses the strategy for realizing competitive advantage to manage the distribution process of innovative products.

The range of products produced by PJSC "Sumykhimprom" is quite wide, however, $95 \%$ of the products produced by the company are titanium dioxide and mineral fertilizers. It should be noted that PJSC "Sumykhimprom" is the only producer of titanium dioxide on the territory of Ukraine (the products of the company "Crimean Titan" are absent in the market of Ukraine due to the annexation of the ARC) [37]. Therefore, the focus should be placed on this type of product.

Titanium dioxide is the most important white pigment in the world. The global titanium dioxide market is rapidly developing, primarily because it can be widely used in various industries.

Titanium dioxide is added to the paints to make them white, bright and to improve the quality of the coating. Also, titanium dioxide is used in the pulp and paper industry for bleaching; during the production of synthetic fibers and fabrics; in cosmetics; in radio electronics; in the healthcare and food industries, etc. [37].

Taking into the wide scope of the use of dioxide we can talk about the growing importance 
of it for consumers, and consequently, about the growth of benefits for consumers.

The growth rates of prices for titanium dioxide during 2012-2018 are in Fig. 7.

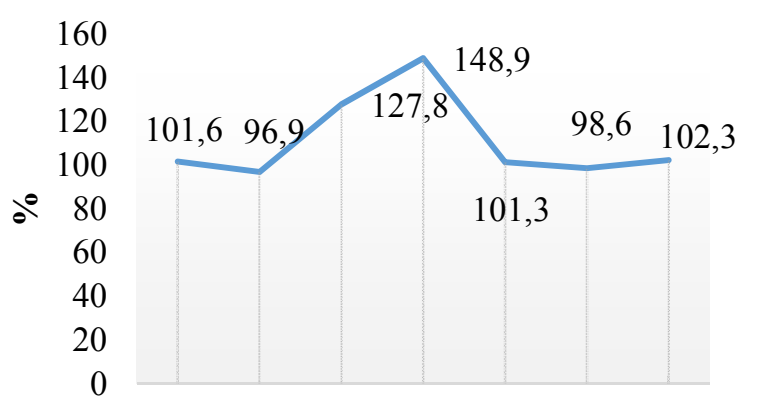

2012201320142015201620172018

Years

Fig. 7. Prices dynamics for titanium dioxide at PJSC "Sumykhimprom" in 2012-2018

The value of the indicator that takes into account the benefits that consumers receive from titanium dioxide is calculated based on the estimation parameters specific to this type of innovative product (Table 3). We consider 6 product brands produced by the company: SumTITAN R-204, SumTitan R-206 (standard brands), SumTitan R-2041, SumTitan R-2061, SumTitan R-2071, SumTitan R-208.

Table 3. Characteristics of titanium dioxide

\begin{tabular}{|c|c|c|c|c|c|c|c|}
\hline 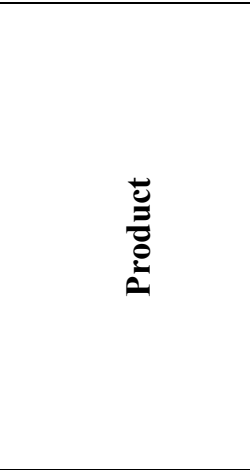 & 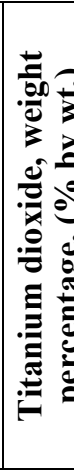 & 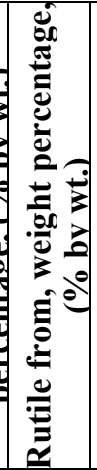 & 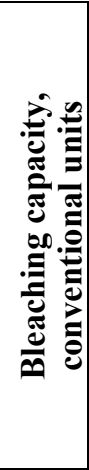 & 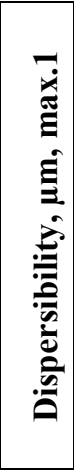 & 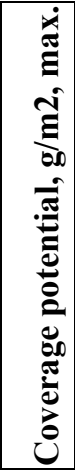 & 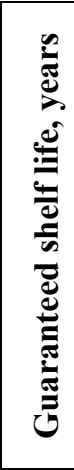 & 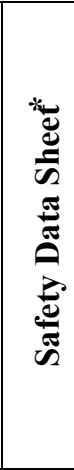 \\
\hline $\begin{array}{l}\text { SumTitan R-204, } \\
\text { SumTitan R-206 } \\
\text { (standart) }\end{array}$ & 94 & 97 & 2000 & 45 & 25 & 1 & 1 \\
\hline SumTitan R-2041 & 94 & 97 & 2050 & 40 & 24 & 1 & 1 \\
\hline SumTitan R-2061 & 94 & 97 & 2000 & 40 & 24 & 1 & 1 \\
\hline SumTitan R-2071 & 95 & 98 & 2100 & 35 & 24 & 1 & 1 \\
\hline SumTitan R-208 & 93 & 98 & 2100 & 35 & 24 & 1 & 1 \\
\hline Optimal value & $\begin{array}{c}95 \\
\max \end{array}$ & \begin{tabular}{|c|}
98 \\
$\max$ \\
\end{tabular} & $\begin{array}{c}2100 \\
\max \end{array}$ & $\begin{array}{c}35 \\
\text { min } \\
\end{array}$ & \begin{tabular}{|c|}
25 \\
$\max$ \\
\end{tabular} & $\begin{array}{c}1 \\
\max \end{array}$ & $\begin{array}{c}1 \\
\max \end{array}$ \\
\hline Weighting & 0.16 & 0.16 & 0.16 & 0.16 & 0.16 & 0.1 & 0.1 \\
\hline
\end{tabular}

Notes: “*” - "Safety Data Sheet”: 1 - Safety Data Sheet is available, 0 - no Safety Data Sheet available.

Source: Own compilations (based on [36])

The weighting characteristics of indicators were also determined for the calculation of the integrated indicators of benefits. Since all the determined indicators are important, their weighting is almost equal.

$$
\begin{gathered}
\mathrm{P}_{\text {Standard }}=0,16 \cdot \frac{94}{95}+0,16 \cdot \frac{97}{98}+0,16 \cdot \frac{2000}{2100}+0,16 \cdot \frac{35}{45}+ \\
+0,16 \cdot \frac{25}{25}+0,1 \cdot \frac{1}{1}+0,1 \cdot \frac{1}{1}=0.954 \\
\mathrm{P}_{\text {SumTitan R-2041 }}=0,16 \cdot \frac{94}{95}+0,16 \cdot \frac{97}{98}+0,16 \cdot \frac{2050}{2100}+ \\
\quad+0,16 \cdot \frac{35}{40}+0,16 \cdot \frac{24}{25}+0,1 \cdot \frac{1}{1}+0,1 \cdot \frac{1}{1}=0.966 ; \\
\mathrm{P}_{\text {SumTitan R-2061 }}=0,16 \cdot \frac{94}{95}+0,16 \cdot \frac{97}{98}+0,16 \cdot \frac{2000}{2100}+ \\
\quad+0,16 \cdot \frac{35}{40}+0,16 \cdot \frac{24}{25}+0,1 \cdot \frac{1}{1}+0,1 \cdot \frac{1}{1}=0.963 \\
\mathrm{P}_{\text {SumTitan R-2071 }}=0,16 \cdot \frac{95}{95}+0,16 \cdot \frac{98}{98}+0,16 \cdot \frac{2100}{2100}+ \\
\quad+0,16 \cdot \frac{35}{35}+0,16 \cdot \frac{24}{25}+0,1 \cdot \frac{1}{1}+0,1 \cdot \frac{1}{1}=0.994 \\
\mathrm{P}_{\text {SumTitan R-208 }}=0,16 \cdot \frac{93}{95}+0,16 \cdot \frac{98}{98}+0,16 \cdot \frac{2100}{2100}+ \\
\quad+0,16 \cdot \frac{35}{35}+0,16 \cdot \frac{24}{25}+0,1 \cdot \frac{1}{1}+0,1 \cdot \frac{1}{1}=0.990 .
\end{gathered}
$$

Let's calculate the integrated indicators of benefits by years (the best product is the product, the estimate of which is close to 1) and determine the corresponding growth rates (Fig. 8):

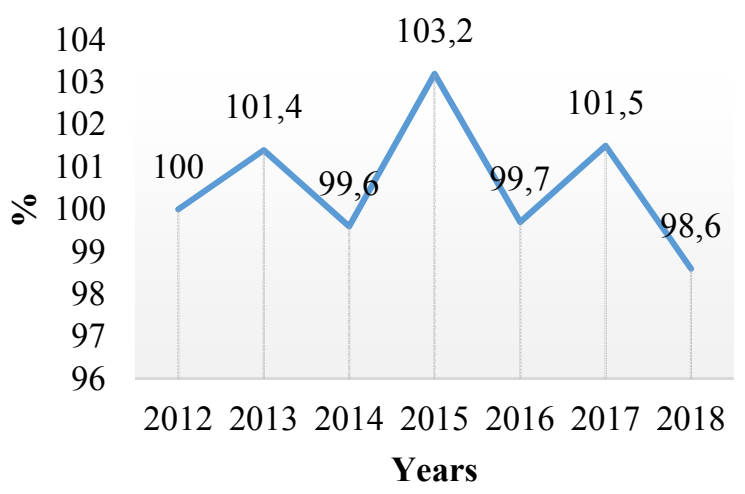

Fig. 8. Dynamics of benefits indicators for titanium dioxide at PJSC "Sumykhimprom" in 2012-2018

Based on the above information, we will evaluate the correspondence between the normative and actual structure of the indicators by (Spearman's coefficient (K) [43]) (Table 4). 
Table 4. Relationship between normative and actual series of indicators from the perspective of the consumer during 2012-2018 for PJSC

\begin{tabular}{|c|c|c|c|c|c|c|}
\hline \multicolumn{7}{|c|}{ "Sumykhimprom" } \\
\hline 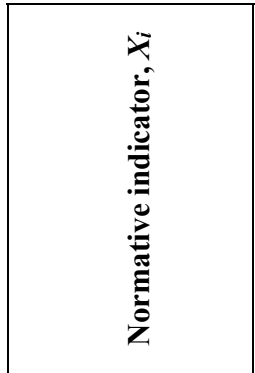 & 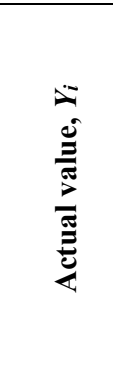 & 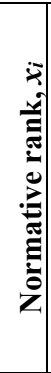 & 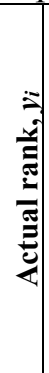 & 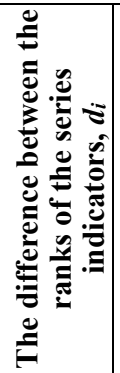 & 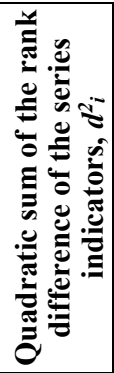 & 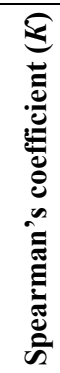 \\
\hline \multicolumn{7}{|c|}{2012} \\
\hline $\begin{array}{l}\text { Growth rate of } \\
\text { prices for products }\end{array}$ & $101.6 \%$ & 1 & 2 & -1 & 1 & \multirow[b]{2}{*}{-1} \\
\hline $\begin{array}{l}\text { The growth rate of } \\
\text { the value of the } \\
\text { benefit indicator }\end{array}$ & $100 \%$ & 2 & 1 & 1 & 1 & \\
\hline \multicolumn{7}{|c|}{2013} \\
\hline $\begin{array}{l}\text { Growth rate of } \\
\text { prices for products }\end{array}$ & $96.6 \%$ & 1 & 1 & 0 & 0 & \multirow[b]{2}{*}{1} \\
\hline $\begin{array}{l}\text { The growth rate of } \\
\text { the value of the } \\
\text { benefit indicator }\end{array}$ & $101.4 \%$ & 2 & 2 & 0 & 0 & \\
\hline \multicolumn{7}{|c|}{2014} \\
\hline $\begin{array}{l}\text { Growth rate of } \\
\text { prices for products }\end{array}$ & $127.8 \%$ & 1 & 2 & -1 & 1 & \multirow[b]{2}{*}{-1} \\
\hline $\begin{array}{l}\text { The growth rate of } \\
\text { the value of the } \\
\text { benefit indicator }\end{array}$ & $99.6 \%$ & 2 & 1 & 1 & 1 & \\
\hline \multicolumn{7}{|c|}{2015} \\
\hline $\begin{array}{l}\text { Growth rate of } \\
\text { prices for products }\end{array}$ & $148.9 \%$ & 1 & 2 & -1 & 1 & \multirow[b]{2}{*}{-1} \\
\hline $\begin{array}{l}\text { The growth rate of } \\
\text { the value of the } \\
\text { benefit indicator }\end{array}$ & $103.2 \%$ & 2 & 1 & 1 & 1 & \\
\hline \multicolumn{7}{|c|}{2016} \\
\hline $\begin{array}{l}\text { Growth rate of } \\
\text { prices for products }\end{array}$ & $101.3 \%$ & 1 & 2 & -1 & 1 & \multirow[b]{2}{*}{-1} \\
\hline $\begin{array}{l}\text { The growth rate of } \\
\text { the value of the } \\
\text { benefit indicator }\end{array}$ & $99.7 \%$ & 2 & 1 & 1 & 1 & \\
\hline \multicolumn{7}{|c|}{2017} \\
\hline $\begin{array}{l}\text { Growth rate of } \\
\text { prices for products }\end{array}$ & $98.6 \%$ & 1 & 1 & 0 & 0 & \multirow[b]{2}{*}{1} \\
\hline $\begin{array}{l}\text { The growth rate of } \\
\text { the value of the } \\
\text { benefit indicator }\end{array}$ & $101.5 \%$ & 2 & 2 & 0 & 0 & \\
\hline \multicolumn{7}{|c|}{2018} \\
\hline $\begin{array}{l}\text { Growth rate of } \\
\text { prices for products }\end{array}$ & $102.3 \%$ & 1 & 2 & -1 & 1 & \multirow[b]{2}{*}{-1} \\
\hline $\begin{array}{l}\text { The growth rate of } \\
\text { the value of the } \\
\text { benefit indicator }\end{array}$ & $98.6 \%$ & 2 & 1 & 1 & 1 & \\
\hline
\end{tabular}

Source: Own calculations

Regarding Spearman's coefficient for consumers, during the analyzed years, except for 2013 and 2017, Spearman's coefficient is equal to -1 , i.e., a negative relationship is observed, because the indicators are placed in the reverse order, this reflects negative correlation.

The growth of Spearman's coefficient to +1 in 2013 and 2017 is caused by the fact that the company made changes to standard brands of titanium dioxide, which led to an increase in the benefits of consumers. The subsequent changes in titanium dioxide brands were less significant.

However, the fact that Spearman's coefficient obtained extreme value -1 during 20142016 and in 2018, it does not mean that the company activities are oriented to the decrease ineffectiveness. First of all, it is worth noting that in 2014 and 2015 there was a significant increase in prices for products caused by the instability of the domestic situation in the country. Accordingly, the growth rate of the benefit indicator was less than the rate of price growth. Although the company is constantly improving its products, including launching new brands of titanium dioxide, their characteristics do not differ significantly, which is the reason for the slow growth of the benefit indicator by years.

The reason for this is that titanium dioxide is a product with unique properties, i.e. it is the main white dye in the world. That is why making significant changes in this product is quite a complex process, which can lead to negative consequences, for example, an increase in the solubility of titanium dioxide or an increase in its capability to interact with acids and alkalis, which is undesirable.

Next, we graphically represent the dynamics of Spearman's coefficient from the perspective of the consumer (Fig. 9).

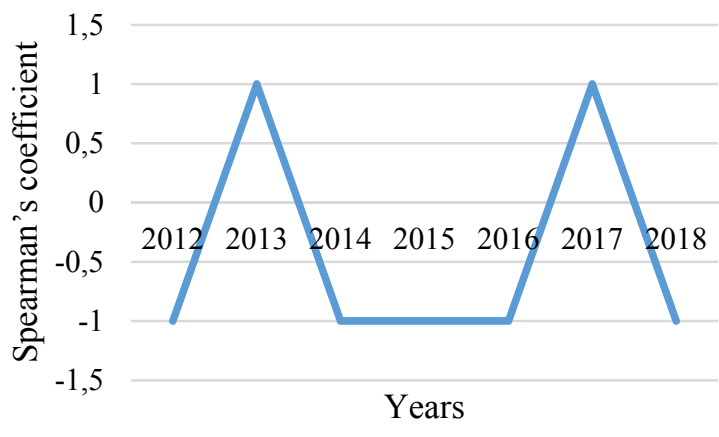

Fig. 9. Dynamics of Spearman's coefficient from the perspective of consumer during 2012-2018 for PJSC "Sumykhimprom"

Accordingly, it can be noted that the company needs to review the current strategy of distribution management, taking into account the actual state of the indicators.

The findings indicate potential the following recommendations for PJSC "Sumykhimprom" to 
improve the strategy:

1. The company needs to control the prices of its products. In particular, regarding titanium dioxide, there was a variation in prices during 2012-2018 - their gradual reduction or increase. Such sharp leaps in prices, especially towards their increase, can be negatively perceived by consumers and "push" them to look for new suppliers of products at a lower price.

2. Products of the company are unique and have specific characteristics, the improvement of which is a long and complex process. Accordingly, the benefits that consumers receive from the use of products grow slowly. However, the company continues to develop new types of products and to improve existing ones, which will help to keep the interest of regular consumers and attract new ones.

3. The most effective strategy of innovative product's distribution policy management is logistic innovation strategy. It includes the logistical support of the innovation process which should help to minimize costs, to reduce the timeframe of the innovation project cycle, to improve quality of innovative product, to increase the life cycle of innovative product, to increase operational and ecological productiveness of the product.

\section{Conclusion}

Thus, in addition to existing methodological approach to evaluating the strategy of distribution management this one allows to increase its objectivity from the consumer's perspectives based on the correspondence between the normative and actual structure of the indicators of prices for innovative products and the benefits received by consumers. It determines the compliance of the strategy with their expectations. The results of the evaluating the strategies of distribution management for innovative products should be use by the chemical companies in the strategic planning, marketing and logistic management. They are aimed at the efficient organization and functioning of supply, production, commodity circulation and the sale of innovative products. This approach provides the effective management of distribution and timeliness of decisions on adjustment of strategic management actions in chemical and other industrial enterprises.

So based on evaluating the strategy of distribution management in logistics it was determined that the strategy for realizing competitive advantage within distribution management is unstable and needs to be improved according to the marketing focus to consumers of chemical companies (a case study of PJSC "Sumykhimprom"). First of all, this is due to variation in prices for products, their periodic sharp increase and the specifics of products, whose benefits indicators are increasing at a slow pace. This is also evidenced by Spearman's coefficients, because according to them in all analyzed years, except for 2013 and 2018, there is an inverse relationship between the actual performance indicators and their normative values.

According to the above, the process of strategy implementation by the company is complicated by current circumstances and requires support and control by the management. In addition, to improve the strategy of distribution management, it is also necessary to follow the main international trends in the chemical industry (innovation, digitalization, integration, and ecologization) and to take into account dynamics of the main indicators on the chemical industry in the global market. It enables us to state that the chemical industry is one of the key industries at the world level. The USA, Japan and the EU are leaders of its industry. In terms of Ukraine, the chemical industry is one of the six classical braches of the Ukrainian economy that are "basic" ones. Despite the growing importance of this industry on a worldwide scale and the local potential available, the Ukrainian chemical industry needs additional capital investments and further development. Prospects for further research in this area should be aimed to the research and comparison of other industrial enterprises in different industries.

\section{Acknowledgements}

The publication contains the results of studies conducted on the state budget research topics "The development of a mechanism for commercialization of innovative products" (0118U003572); "The mechanism of management of the formation of strategies of outstripping innovative development of industrial enterprises" (№ SR 0117U003928); "Development of scientific and methodological foundations and practical tools for evaluating of the product innovations commercial (market) prospects" (№ SR 0119U100179).

\section{References:}

[1] Shkarlet, S., Dubyna, M., Features of the cognitive approach application to the essence 
of the financial services market identification, Economic Annals-XXI, 158(34(2)), 2016, pp. 70-74. http://dx.doi.org/10.21003/ea.V158-16.

[2] Shkarlet, S., Dubyna, M., Vovk, V., Noga, M., Financial service markets of Eastern Europe: a compositional model, Economic Annals-XXI, 176(3-4), 2019, pp. 26-37. https://doi.org/10.21003/ea.V176-03.

[3] Chmutova, I., Vovk, V., Bezrodna, O., Analytical tools to implement integrated bank financial management technologies, Economic Annals-XXI, 163(1-2(1)), 2017, pp. 95-99. https://doi.org/10.21003/ea.V16320.

[4] Definition of Sales Strategy by Sam Amico. Retrieved January 7, 2020, from https://smallbusiness.chron.com/definitionsales-strategy-2213.html.

[5] Zolters, Sinha, Lorimer, cited in Samuel Kuosa, Analysing and Improving the Sales Strategy and Process Case: Robert Bosch Oy. Retrieved February 14, 2020, from https://www.theseus.fi/bitstream/handle/100 24/129374/Kuosa Samuel.pdf?sequence=1.

[6] Official website of HubSpot, Inc. Retrieved February 10, 2020, from https://www.hubspot.com/sales/salesstrategy.

[7] Storbacka, K., Ryals, L., Davies, I., Nenonen, S., The changing role of sales: viewing sales as a strategic, cross-functional process. European Journal of Marketing, Vol. 43, No. 7/8, 2009, pp. 890-906. Retrieved February 9, 2020, from https://core.ac.uk/download/pdf/140054.pdf.

[8] Illiashenko, S., Strategic management of enterprise innovative activity basing on marketing of innovations, Actual Problems of Economics, (12), 2010, pp. 111-119.

[9] Babenko, V.A., Formation of economicmathematical model for process dynamics of innovative technologies management at agroindustrial enterprises. Actual Problems of Economics, 139 (1), 2013, pp. 182-186.

[10] Babenko, V., Nakisko, O., Latynin, M., Rudenko, S., Lomovskykh, L., and Girzheva, O. (2019). Procedure of Identifying of the Parameters of the Model of Management of Technological Innovations in Economic Systems, 2019 IEEE International ScientificPractical Conference Problems of Infocommunications, Science and Technology (PIC S\&T), Kyiv, Ukraine, 324328.
10.1109/PICST47496.2019.9061259

[11] Hrabovskyi, Y., Babenko, V., Al'boschiy, O., Gerasimenko, V. (2020). Development of a Technology for Automation of Work with Sources of Information on the Internet. WSEAS Transactions on Business and Economics, Vol. 17, Art. \#25, pp. 231-240. doi: 10.37394/23207.2020.17.25

[12] Pererva, P., Besprozvannykh, O., Tiutlikova, V., Kovalova, V., Kudina, O., Dorokhov, O., Improvement of the Method for Selecting Innovation Projects on the Platform of Innovative Supermarket. TEM Journal, 8 (2), 2019, pp. 454-461. https://doi.org/10.18421/TEM82-19.

[13] Huang, S., Jiang. H., Multimodal estimation of distribution algorithm based on cooperative clustering strategy. Chinese Control And Decision Conference (CCDC), Shenyang, 2018, 5297-5302. Retrieved February 14, 2020, from https://ieeexplore.ieee.org/document/840805 2. doi: 10.1109/CCDC.2018.8408052.

[14] Wang, L., Fan, H., Gong, T., The Consumer Demand Estimating and Purchasing Strategies Optimizing of FMCG Retailers Based on Geographic Methods. Sustainability, $10,2018$. https://doi.org/10.3390/su10020466.

[15] Kurbatska, L., Ilchenko, T., Kadyrus, I., Theoretical aspects of marketing support for an effective distribution policy in an agricultural enterprise. Scientific bulletin of Kherson State University, 21 (1), 2016, pp. 122-126. Retrieved February 14, 2020, from https://dspace.dsau.dp.ua/jspui/bitstream/123 $456789 / 240 / 1 / \% \mathrm{~d} 0 \% \mathrm{a} 1 \% \mathrm{~d} 1 \% 82 \% \mathrm{~d} 0 \% \mathrm{~b} 0 \% \mathrm{~d}$ $1 \% 82 \% \mathrm{~d} 1 \% 82 \% \mathrm{~d} 1 \% 8 \mathrm{f} \% \mathrm{~d} 0 \% 9 \mathrm{a} \% \mathrm{~d} 1 \% 83 \%$ $\mathrm{d} 1 \% 80 \% \mathrm{~d} 0 \% \mathrm{~b} 1 \% \mathrm{~d} 0 \% \mathrm{~b} 0 \% \mathrm{~d} 1 \% 86 \% \mathrm{~d} 1 \% 8 \mathrm{c} \%$ d0\%ba $\% \mathrm{~d} 0 \% \mathrm{~b} 0 \% 2 \mathrm{c} \% 20 \% \mathrm{~d} 0 \% 86 \% \mathrm{~d} 0 \% \mathrm{bb} \%$ d $1 \% 8 \mathrm{c} \% \mathrm{~d} 1 \% 87 \% \mathrm{~d} 0 \% \mathrm{~b} 5 \% \mathrm{~d} 0 \% \mathrm{bd} \% \mathrm{~d} 0 \% \mathrm{ba} \%$ d0\%be $\% 2 \mathrm{c} \% 20 \% \mathrm{~d} 0 \% 9 \mathrm{a} \% \mathrm{~d} 0 \% \mathrm{~b} 0 \% \mathrm{~d} 0 \% \mathrm{~b} 4 \%$ d0\%b8\%d1\%80\%d1\%83\%d1\%81.pdf.

[16] Polishchuk, I., Evaluation of effectiveness of enterprise marketing strategy. Problems of theory and methodology of accounting, control and analysis, 3 (33), 2015, pp. 259271. Retrieved February 14, 2020, from http://eztuir.ztu.edu.ua/bitstream/handle/1234 $56789 / 2582 / 24$.pdf? sequence $=1 \&$ isAllowed $=$ y.

[17] Bilovodska, O., Forming and Implementing Investment Strategies for Innovative Development of Enterprises: Essence, Main Components and Evaluation. Business 
Inform, 11, 2016, pp. 204-210.

[18] Landscape of the European Chemical Industry. Retrieved February 10, 2020, from https://www.chemlandscape.cefic.org/wpcontent/uploads/pdfs/EU28-23.pdf.

[19] Official website of European Commission. Chemicals. Retrieved February 10, 2020, from

https://ec.europa.eu/growth/sectors/chemicals en.

[20] Chemicals trends analyzer. Retrieved January 7 , 2020, from https://www.ey.com/Publication/vwLUAsset s/ey-chemicals-trends-analyzer/\$FILE/eychemicals-trends-analyzer-may-2017.pdf.

[21] Trends in the chemical industry. Official website of BASF Group. BASF Online Report 2016. Retrieved May 06, 2020, from https://report.basf.com/2016/en/management s-report/basf-group-business-year/economicenvironment/chemical-industry.html

[22] Trends in the chemical industry. Official website of BASF Group. BASF Online Report 2017. Retrieved May 06, 2020, from https://report.basf.com/2017/en/managemen ts-report/basf-group-businessyear/economic-environment/chemicalindustry.html

[23] Trends in the chemical industry. Official website of BASF Group. BASF Online Report 2018. Retrieved May 06, 2020, from https://report.basf.com/2018/en/managemen ts-report/basf-group-businessyear/economic-environment/chemicalindustry.html

[24] Trends in the chemical industry. Official website of BASF Group. BASF Online Report 2019. Retrieved February 14, 2020, from

https://report.basf.com/2019/en/managemen ts-report/basf-group-business-

year/economic-environment/chemicalindustry.html

[25] Trends in the chemical industry. Official website of BASF Group. BASF Online Report 2019. Retrieved May 06, 2020, from http://report.basf.com/2019/en/management s-report/forecast/economicenvironment/chemical-industry.html

[26] Landscape of the European Chemical Industry. Full Report. Retrieved May 08, 2020, from http://www.chemlandscape.cefic.org/wpcontent/uploads/combined/fullDoc.pdf.

[27] Performance Chemicals. Official website of
BASF Group. BASF Online Report 2015. Retrieved May 07, 2020, from https://report.basf.com/2015/en/management s-report/segments/performanceproducts/business-review/performancechemicals.html.

[28] Performance Chemicals. Official website of BASF Group. BASF Online Report 2016. Retrieved May 07, 2020, from https://report.basf.com/2016/en/management s-report/segments/performanceproducts/business-review/performancechemicals.html.

[29] Performance Chemicals. Official website of BASF Group. BASF Online Report 2017. Retrieved May 07, 2020, from https://report.basf.com/2017/en/management s-report/segments/performanceproducts/business-review/performancechemicals.html.

[30] Performance Chemicals. Official website of BASF Group. BASF Online Report 2018. Retrieved May 07, 2020, from https://report.basf.com/2018/en/management s-report/segments/performanceproducts/business-review/performancechemicals.html.

[31] Performance Chemicals. Official website of BASF Group. BASF Online Report 2019. Retrieved May 07, 2020, from http://report.basf.com/2019/en/managementsreport/segments/industrialsolutions/business-review.html.

[32] Chemical Exports by Country. Retrieved May 08, 2020, from http://www.worldstopexports.com/chemical -exports-by-country/

[33] C\&EN's Global Top 50 chemical companies of 2018. Retrieved May 08, 2020, from https://cen.acs.org/business/finance/CENsGlobal-Top-50-chemical/97/i30.

[34] Industry of Ukraine, 2011-2015. Kyiv: State Statistics Service of Ukraine. Retrieved January $7, \quad 2020, \quad$ from http://www.ukrstat.gov.ua/druk/publicat/kat u/publ5_u.htm.

[35] Select USA. The Chemical Industry in the United States. Retrieved February 14, 2020, from https://www.selectusa.gov/chemicalindustry-united-states.

[36] The Global Chemical Industry: Catalyzing Growth and Addressing Our World's Sustainability Challenges. Report for ICCA. Retrieved May 08, 2020, from 
https://www.icca-chem.org/wp-

content/uploads/2019/03/ICCA_EconomicA

nalysis_Report_030819.pdf.

[37] Official website of Public Joint-Stock Company "Sumykhimprom". Retrieved February 10, 2020, from http://sumykhimprom.com.ua/ua/company/

[38] Global Innovation Trends 2019. Retrieved May 06, 2020, from https://medium.com/4thly/globalinnovation-trends-2019-9935c5473064.

[39] Digitalisation - An Unstoppable Mega Trend. Retrieved May 07, 2020, from https://www.institutefordigitaltransformatio n.org/digitalisation-an-unstoppable-megatrend/

[40] 5 Integration Trends to Look For In 2020. Retrieved May 08, 2020, https://adeptia.com/blog/5-integrationtrends-2020.

[41] Bilovodska, O., Gaidabrus, N., Ruban, D., An analytical study on logistics outsourcing impact on logistical service quality in supply chains (case study: industrial enterprises of Sumy region). Problems and Perspectives in Management, 3(15), 2017, pp. 201211. http://dx.doi.org/10.21511/ppm.15(31).2017.04.

[42] Bilovodska, O., Gryshchenko, O., Syhyda, L., The marketing channel structure: A case of chemical industry company. Periodicals of Engineering and Natural Sciences, 7 (2), 2019, pp. 741-751. http://dx.doi.org/10.21533/pen.v7i2.556.g34 0 .

[43] Spearman's rank correlation coefficient. Retrieved February 22, 2020, from https://math.semestr.ru/corel/spirmen.php 